\title{
Supply Chain Integration: Establish the Appropriate Challenges in Improving Integrated SC in an Innovative Approach of IBS
}

\author{
Ani Saifuza Abd Shukor ${ }^{*}$, Muhammad Fadhil Muhammad², \\ Shamsida Saidan Khaderi ${ }^{3}$, Faridah Muhammad Halil ${ }^{4}$ \\ ${ }^{1}$ Centre of Studies for Quantity Surveying,Faculty of Architecture, Planning \& Surveying,Universiti Teknologi MARA (UiTM), 40450 Shah Alam, \\ Malaysia
}

\begin{abstract}
The shift to an integrated IBS construction approach requires enhanced supply chain integration to improve the productivity as well as the poor quality of human behavioual aspect in IBS project. This paper is to identify the challenges at each tier between players to facilitate supply chain integration among the IBS players. Findings adopted from semi-structured interview revealed the critical attitude issues of human factors, lack of interaction and sharing knowledge between interdisciplinary people. The findings of this study is useful to improve integration of supply chain and enhance innovation and sharing interaction between players in the IBS Malaysian construction project environment.
\end{abstract}

(C) 2016. The Authors. Published for AMER ABRA by e-International Publishing House, Ltd., UK. This is an open access article under the CC BY-NC-ND license (http://creativecommons.org/licenses/by-nc-nd/4.0/).

Peer-review under responsibility of AMER (Association of Malaysian Environment-Behaviour Researchers), ABRA (Association of Behavioural Researchers on Asians) and CE-Bs (Centre for Environment-Behaviour Studies), Faculty of Architecture, Planning \& Surveying, Universiti Teknologi MARA, Malaysia.

Keywords: Construction Environment; Industrialised Building System; Integration and Supply Chain

\section{Introduction}

The Malaysian Construction Industry Master Plan (CIMP 2006-2015) and the present Construction Industry Transformation Programme (CITP 2016-2020) identified the innovative approaches of Industrialised Building Systems (IBS) and its Supply Chains (SC) as having important roles in improving productivity in construction processes. SC in IBS involves relationships between many organisations and processes, with the evolution of specialised roles and embedded relationships. The procurement method is utilised as a mediator tool and as the means of controlling integration between players. A SC integration practice leads to good integration among players. The growing interest in IBS has also been noticed across the globe; for instance, it has been emphasised as a

\footnotetext{
* Corresponding author. Tel.: +6-019-3983172

E-mail address:asaswan74@yahoo.com
}

2398-4287 @ 2016. The Authors. Published for AMER ABRA by e-International Publishing House, Ltd., UK. This is an open access article under the CC BY-NC-ND license (http://creativecommons.org/licenses/by-nc-nd/4.0/).

Peer-review under responsibility of AMER (Association of Malaysian Environment-Behaviour Researchers), ABRA (Association of Behavioural Researchers on Asians) and CE-Bs (Centre for Environment-Behaviour Studies), Faculty of Architecture, Planning \& Surveying, Universiti Teknologi MARA, Malaysia.

DOI: http://dx.doi.org/10.21834/e-bpj.v1i3.351 
channel for innovation and change in thinking and working processes in the UK construction industry (Gibb, 1999; Nadim \& Goulding, 2010). A considerable amount of literature has been published on IBS. An analysis done by Dulaimi et al. (2001) on lessons learnt from government reports across the globe highlighted that off-site production or IBS, standardisation and integrating the supply chain would drive development in enhanching performance in the delivery of construction project. Given the scenarios of excessive foreign workers, low levels of productivity and quality of construction industry, these provide the impetus for IBS implementation in the Malaysian construction industry IBS is a strategy for transforming the construction industry into an industrialised sector that deals with prefabricated components. However, changes from conventional methods to IBS construction methods need the construction supply chains to be well integrated to better adapt and understand the design and production of building elements (Warszawski, 1999). Therefore, in response to the numerous benefits and the government's aspirations, a series of supports and initiatives have been designed to educate the Malaysian construction supply chains in order to move IBS implementation forward. Nonetheless, the IBS project delivery has attracted much criticism and raises challenges that need to be overcome, mostly related to the supply chains and integration (Abd Shukor et al., 2009; CIDB, 2007; CREAM, 2009a; Faizul, 2006; Hamid et al., 2008). One of the most crucial problems in IBS is: Lack of Supply Chain Integration and Togetherness. To realise the government's aspirations in moving towards a more efficient IBS project procurement delivery, there is an urgent need and a wholesome effort by relevant players within the industry to determine the appropriate challenges factors to improve the integration between each tier of supply chains, especially in Design and Build project procurement

\section{Industrialised building system (IBS)}

The prime notion of IBS is to move from a construction site setting to a manufacturing setting. Higher IBS adoption demands higher innovation towards the new mode of technology. IBS requires a high level of coordination and integration of the supply chains from the design, manufacturing and construction. In line with the new direction of the Malaysian construction industry master plan, the Government is indirectly forcing all the construction supply chains to be committed to enhancing the IBS construction project delivery. Much of the previous research into IBS has focused on the 'hard elements' of the IBS. There has been little research done to investigate the 'soft elements', and relatively little attention have been given to supply chain issues. Haron et al. (2009) have noted that not many studies have been conducted on "soft elements" of IBSs, especially on the Construction Supply Chain Management as researchers are more focused on IBS components, structural design systems and the advanced technology construction process. Hence, there appears to be a substantial gap between the soft and hard element of research. Thus, to enhance the level of adoption of IBS to be successful to any approach aimed at creating industrial structures in the construction industry, it must not only look at the hard aspects but extend beyond to the soft aspects of management. Therefore, the implementation of IBS in the Malaysian construction industry has been recognised as a potential approach to reducing the dependency on foreign labour, reduce waste, speed up completion, enhance quality, reduce cost and introduce more repetitive and integrated ways of working (CIDB, 2007; Jabar et al. 2013).Thus, keeping in mind the importance of improving the integration of the supply chain in IBS implementation, its challenges should be considered and acknowledged in order to persuade the construction industry to engage in a more systematic and strategic approach to IBS construction, especially in respect of the fragmented supply chains and improve the quality of working practices.

\section{Integrated supply chain and the challenges}

In the construction industry, all construction companies, be they Client, Contractor, Designer, Sub-contractor, or Supplier, are therefore parts of a supply chain (Xue et al., 2005). It is the client together with all of these organisations that form the supply chain to deliver the project (Brown, 1999). The fragmented and adversarial nature of the construction industry extensively influences the performance and the characteristics of construction supply chains and affects the integration of the supply chain. The Malaysian construction industry therefore desperately needs a wholesome effort by relevant players within the industry to search for the most appropriate factors to 
improve the integration between each tier of supply chains. This attempt is in line with the suggestion by Pan et al.(2005) who declared that off-site construction should be improved, where the industry players, especially house builders, manufacturers or suppliers should be integrated at the early stage. The scene of the fragmented construction project practices from temporary organisations on a project-by-project basis results in the supply chains of construction project practice having different manner (Jitpaiboon, 2005) sets of goals and priorities and unsatisfactory project delivery outcome (Emuze \& Smallwood, 2011). Kennedy and Sidwell (2001) suggested that restructuring the systems and procedures for delivering projects will enhance the benefits to the ends users. Difficulty in integrating is attributed to the variety of professions and skills involved in the project delivery. In the case of Malaysia, to improve integration of supply chain construction practices they need to be in touch with current trends and practices to boost competitiveness and innovation. Therefore, in the view of Jitpaiboon (2005) to take full advantage of the benefit of the integration of the supply chain, all the supply chain members should continuously be aware of every key activity and need to work together to enhance their relationships and interaction. The literature review indicates that the productivity and performance of the construction project are achieved by positive integration of the supply chains involved. A review and analysis of the generic integration definitions uncovered that the term "integration" itself can be viewed as the bringing and work together of different disciplines in a cohesive. It can be noted that integration has the characteristics of working together, interaction and collaboration, project common goals and objectives, sharing information and knowledge and aligning the behaviour. Numerous challenges in construction supply chains and IBS particularly should be addressed extensively to enhance the productivity (Awad \& Nassar,2010). The prime objective of this paper is to determine the appropriate challenges factors to improve the integration between each tier of supply chains, thus there is a need for the IBS construction industry to recognise the challenging factors that hinder supply chain integration and be able to recognise the benefits from an integrated supply chain. Table 1 lists the supply chain integration challenges found in the reviewed literature.

Table 1. Supply Chain Integration Challenges

\begin{tabular}{|c|c|c|}
\hline Theme & Challenges & References \\
\hline Attitude Related Issues & $\begin{array}{l}\text { Selfish interest, Short-term focus, } \\
\text { Arrogant, Ignorance of others' needs, } \\
\text { Reluctant to adopt attitudinal change, } \\
\text { Short term thinking, Ignorance of } \\
\text { others' contribution }\end{array}$ & $\begin{array}{l}\text { (Dainty et al., 2001;Matipa \& Siamuzwe, } \\
\text { 2005; Ward \& Holti, 2006; Xue et al., } \\
\text { 2007) }\end{array}$ \\
\hline Information and & Poor information quality, Less & ( Matipa \& Siamuzwe, 2005; Vrijhoef \& \\
\hline $\begin{array}{l}\text { Communication Related } \\
\text { Issues }\end{array}$ & $\begin{array}{l}\text { transparency, Inadequate information, } \\
\text { Failure to share ideas, Long lead to } \\
\text { respond to tasks, inaccurate } \\
\text { documents }\end{array}$ & $\begin{array}{l}\text { Koskela, 1999; Ward \& Holti, 2006; Xue } \\
\text { et al., 2007) }\end{array}$ \\
\hline $\begin{array}{l}\text { Financial/Cost Related } \\
\text { Issues }\end{array}$ & $\begin{array}{l}\text { Transaction Cost, Prompt Client } \\
\text { Payment, Capital cost }\end{array}$ & (Dainty et al., 2001; Xue et al., 2007) \\
\hline $\begin{array}{l}\text { Programming/time Related } \\
\text { Issues }\end{array}$ & $\begin{array}{l}\text { Unrealistic programme times, } \\
\text { Uncertain lead time of materials and } \\
\text { equipment, Late placed orders, } \\
\text { Damaged material, Poor time } \\
\text { coordination }\end{array}$ & $\begin{array}{l}\text { ( Dainty et al., 2001; Ward \& Holti, 2006; } \\
\text { Xue et al., 2007) }\end{array}$ \\
\hline Knowledge Understanding & $\begin{array}{l}\text { Lack of client role understanding, Lack } \\
\text { of understanding the methods and } \\
\text { techniques integration, SCM } \\
\text { knowledge, Lack of essential expertise, } \\
\text { Lack understand the activities and } \\
\text { project operations }\end{array}$ & $\begin{array}{l}\text { (Awad \& Nassar, 2010; Holti et al., 2000; } \\
\text { Ward \& Holti, 2006) }\end{array}$ \\
\hline Contractual and & Fragmentation of Design, Bid and & (Forgues \& Koskela, 2009; Matipa \& \\
\hline Procurement & $\begin{array}{l}\text { Build, Too many procurement paths, } \\
\text { Lowest price, Exclusion of early } \\
\text { involvement of supply chain, Poor } \\
\text { structure and contractual arrangement, } \\
\text { Unfair contract conditions }\end{array}$ & $\begin{array}{l}\text { Siamuzwe, 2005; Morton, 2008; Ward \& } \\
\text { Holti, 2006) }\end{array}$ \\
\hline $\begin{array}{l}\text { Insurance and } \\
\text { Requirements }\end{array}$ & $\begin{array}{l}\text { Professional indemnity insurance, } \\
\text { Clear policy and intention, Client brief }\end{array}$ & $\begin{array}{l}\text { (Baiden, 2006; Holti et al., 2000; Platten } \\
\text { \& Gorse, 2010) }\end{array}$ \\
\hline
\end{tabular}




\section{Methodology}

The semi-structured interviews were used to gain in-depth knowledge of the concepts or variables being studied. This study was undertaken to gain insight and in-depth perspectives from the multiple participants on improving integration challenges and to appreciate and understand attitudes and behaviours of the IBS supply chain members within the IBS project procurement delivery system. Purposive sampling was used throughout these semistructured interviews. According to Piaw (2012), respondents in purposive sampling are chosen because they fulfil certain characteristics required for the research aim. Thus, in this research, the primary consideration in purposive sampling was the judgment of which people could provide the best information to achieve the research objectives since the limitation of the reintroduction scene of IBS in the Malaysian construction industry leaves for a small sampling pool at this time. Thus, the research investigated the interaction of up to five different tiers of the supply chain, encompassing clients, designers, contractors, manufacturers/system providers and installers. The semistructured interviews carried out with managing directors or senior staff, designers, main contractors and system provider/manufacturer organisations deeply involved and experienced in the IBS approach. Usually in an installer organisation, those interviewed were director/owners or senior managers. Based on those suitable criteria, 35 interviews spanning the five different supply chains were carried out (Table 2). The concern of the research was to gather multiple sources of evidence that would validate the general findings and remove any subjective bias that might arise from looking at either a single client or single project supply chain. This present research adopted conceptual or thematic analysis, which can be regarded as establishing the existence and frequency concept most often represented by the words or phrases in the text. In the conceptual analysis, the coded concepts were analysed based on the quantification, occurrence, and harmonizing until its existence. The analysis of the qualitative data generated in semi-structured interviews was conducted using NVivo9. NVivo9 is a content analysis tool that handles rich-text based information, where deep levels of analysis on both small and large volumes of data are required. In this research study, semi-structured interviews were transcribed verbatim. In some cases, the text had to be translated into English. Then, it was transferred to the Nvivo9 system. For this research, a cognitive map was developed from the modelling application. The cognitive map shows and distinguishes to coordinate ideas and identify relationships in a hierarchal manner. To compare directly what different IBS supply chains have said about the challenges, a matrix-coding query with attribute values was used for comparative purposes between attributes. The numeric output from a matrix-coding query provides a basis for a comparative pattern analysis.

Table 2: Assigned Code for Respondents

\begin{tabular}{c|ll}
\hline $\begin{array}{l}\text { Assigned } \\
\text { Code }\end{array}$ & Organisations As An IBS Player & Position Held \\
\hline C1 & Client/ Implementer & \\
C2 & Client/ Implementer & Quantity Surveyor \\
C3 & Client/ Implementer & Senior Principal Assistant Director \\
C4 & Client/ Implementer & Senior Principal Assistant Director \\
DA1 & Designer & Senior Principal Assistant Director \\
DA2 & Designer & Project Director \\
DE3 & Designer & Architect \\
DA4 & Designer & Principal \\
DE5 & Designer & Senior Architect \\
DA6 & Designer & Director \\
DE7 & Designer & Project Architect \\
DA8 & Designer & Senior Engineer \\
DA9 & Designer & Associate Partner \\
DE 10 & Designer & Architect \\
DA 11 & Designer & Managing Director \\
DA 12 & Designer & Assistant Director \\
MC 1 & Main Contractor & Project Architect \\
MC 2 & Main Contractor & Senior General Manager \\
\hline
\end{tabular}




\begin{tabular}{c|ll}
\hline MC 3 & Main Contractor & Project Manager \\
MC 4 & Main Contractor & Contract Manager \\
MC 5 & Main Contractor & Project Manager \\
MC 6 & Main Contractor & Construction Manager \\
MC 7 & Main Contractor & Project Manager \\
MC 8 & Main Contractor & Contract Manager \\
MC 9 & Main Contractor & Project Manager \\
MC 10 & Main Contractor & General Manager Construction \\
P1 & System Provider/Manufacturer & Executive Design Engineer \\
P2 & System Provider/Manufacturer & Sales \& Marketing Manager \\
P3 & System Provider/Manufacturer & Manager Project \\
P4 & System Provider/Manufacturer & Director \\
P5 & System Provider/Manufacturer & Chief Executive Officer \\
I1 & Installer & Project Executive \\
I2 & Installer & Manager \\
I3 & Installer & Managing Director \\
I4 & Installer & Director \\
\hline
\end{tabular}

\section{Findings and discussion}

The findings will focus on the responses from the respondents in identifying the integration challenges that they faced within their current IBS project procurement adopted. Fig.1 and Fig.2 illustrates the cognitive map that indicates the themes driven from the data that relates to the challenges between the players to facilitate the integration of supply chain amongst the players. The integration challenges are grouped into 8 (eight) key categorical themes as (1) lack of sufficient knowledge, understanding an d familiarity; (2) attitude and mentality; (3) financial matters; (4) work planning and arrangement; (5) flow and interaction of supply chain; (6) guidelines and requirements; (7) risk and conflict liability and (8) contractual and procurement matters

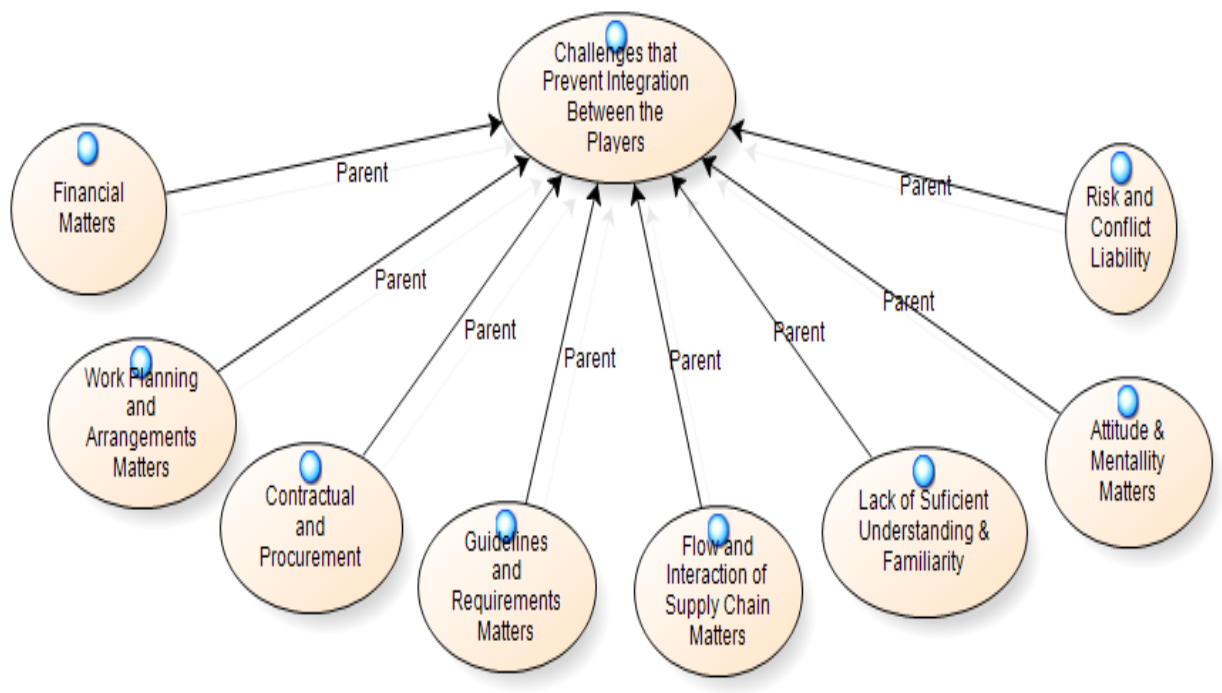

Fig 1. Cognitive Mapping of the Challenges' Integration Themes

\section{a. Lack of sufficient knowledge, understanding and familiarity}

The results consistently showed that clients, designers, contractors and system providers/manufacturers cited lack of sufficient knowledge, understanding and familiarity most frequently as the main challenge in the integration of 
IBS supply chains. For installers, lack of sufficient knowledge, understanding and familiarity was the second most frequently cited challenge. This suggests that the upper tiers find a lack of knowledge and understanding to be one of the most important challenges regarding IBS supply chain integration. While the results showed that the majority of respondents (clients, designers, contractors, system providers/manufacturers and installers) had difficulties understanding IBS construction, each supply chain player had their specific knowledge difficulties. For example, some clients claimed that their lack of knowledge and familiarity with IBS was due to the limited availability of system providers/manufacturers in the market. The majority of designers admitted to having a lack of sufficient understanding of IBS design. Contractors noted their lack of familiarity with IBS processes and components as well as the limited knowledge of system providers/manufacturers regarding various types of projects, especially complicated projects and those involving large volumes. System providers/manufacturers stated that all players in the IBS supply chain, especially the designers, were unfamiliar with the manufacturing process. Finally, installers noted that the site staff (designers and contractors) did not understand the drawings and IBS requirements, which made interaction and integration difficult. The negative impact of lack of knowledge, understanding and familiarity on IBS supply chain integration is supported by information in the literature. Studies have shown that poor human capital development regarding knowledge and understanding of IBS and SCM affects the whole construction supply chain and hinders integration (Kamar \& Hamid, 2011).

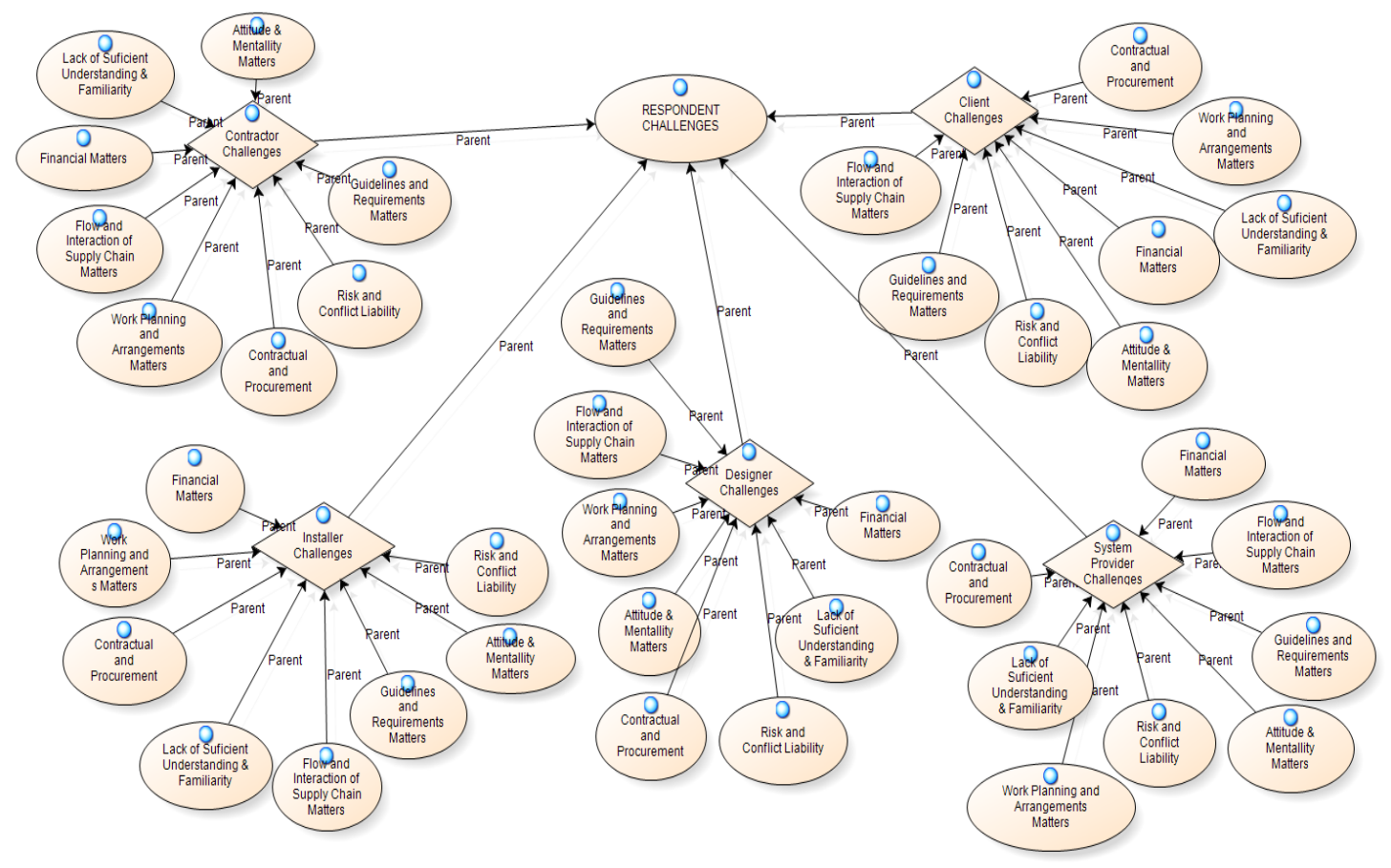

Fig 2. Cognitive mapping of the Challenges' Integration Themes Between IBS Players

\section{b. Attitude and mentality matters}

The results of data analysis emphasise the fact that attitude and mentality play an important role in IBS supply chain integration. The majority of respondents criticised the lack of proper attitude and mentality that prevented improvements in integration between IBS supply chains. The general complaint was that the majority of IBS supply chains maintained a conventional mindset. For all IBS supply chain players (clients, designers, contractors, system providers/manufacturers and installers) the majority of respondents reported that attitudes behaviour were difficult to change and that, consequently, long-term integration took time. The majority of contractors criticised the attitude and mentality of the designers. The contractors felt that the designers insisted on using conventional processes and were reluctant to change. Contractors and system providers/manufacturers criticised the pride and arrogance of 
designers regarding their design concepts. There were complaints that the designers were not concerned with the needs of others in the IBS supply chain and suggestions that designers should be more open minded regarding new practices associated with IBS. Installers complained about the attitude and mentality of site representatives, contractors and project managers. These results are consistent with factors previously identified in the literature. Studies have shown that negative attitudes, such as arrogance, selfishness, short-term focus and ignorance of the needs and contributions of others, prevent integration of construction supply chains (Matipa \& Siamuzwe, 2005).

\section{c. Financial matters}

All IBS supply chains reported financial matters as one of the challenges of supply chain integration. However, regarding priority rankings, clients and system providers/manufacturers ranked financial matters as the second highest challenge, installers and contractors ranked financial matters as the third highest challenge, and designers ranked financial matters lowest of the eight integration challenges. Clients, designers and contractors placed emphasis on payment mechanisms and the difficulties in paying for materials off site. The current payment arrangement for Design and Build procurement is the direct payment concept, which has been identified as a source of misunderstanding and conflict in regard to interactions and integration among designers and contractors. Moreover, system providers/manufacturers and installers mentioned the capability of, and commitment to, prompt payment in regard to financing costs and cash flow. In regard to the literature, Blismas and Wakefield (2009) noted that IBS players will need more reliable payment mechanisms and contracts if conventional methods are replaced with IBS construction. Furthermore, Blismas and Wakefield (2009) noted that IBS incurs high initial and set-up costs, and many manufacturers require at least partial payment once components have been fabricated.

\section{d. Work planning and arrangement}

The unique characteristics of IBS construction present challenges regarding effective project management. According to Blismas and Wakefield (2008), IBS prefabrication requires a coherent process for program implementation and management. Findings showed that clients, designers, contractors, system providers/manufacturers and installers all reported facing challenges related to insufficient construction periods. Designers encountered time constraints for IBS drawings, and contractors and system providers/manufacturers expressed challenges with design development and time integration with other IBS supply chains

\section{e. Flow and interaction of supply chains}

The results demonstrate that the majority of IBS supply chain players noted challenges regarding flow and interaction of supply chain. Clients and contractors complained about communication flow, suggesting that too many people were involved in project delivery. Furthermore, clients, designers, contractors, system providers/manufacturers and installers noted that slow, incomplete and inaccurate flows of information impacted the quality of communication and information among IBS supply chains. Designers and contractors highlighted communication and information flow as important challenges in IBS project procurement and delivery. Lack of transparency and low levels of trust also affected integration. In the literature, Dainty et al. (2001) found that one of the main themes in the obstruction of supply chain integration was the quality of information. They revealed that inaccurate information and missing project-related data presented challenges to integration between the main contractor and the subcontractor. Limited information, loose communication, changes of staff and low levels of trust throughout supply chains have also been found to impede supply chain integration (Ward \& Holti, 2006).

\section{f.Guidelines and requirements matters}

Government The government introduced a policy requiring the use of no less than $70 \%$ IBS components in government projects. As a result, IBS construction in public projects must adhere to policy requirements. The results of this study show that these guidelines and work requirements are a source of distress for designers, contractors and system providers/manufacturers. Designers, contractors and system providers/manufacturers identified 
guidelines and requirements as challenges to integration. Designers noted conflicts in the guidelines and requirements regarding measurements that suit IBS modular design and the element in IBS scoring. On the other hand, contractors and system providers/manufactures complained about the lack of standard policies and guidelines on client needs that complicate component production delivery. The importance of IBS scoring systems has been highlighted in the literature. Baiden (2006) stated that client needs and clear policy intentions should be clearly considered and spelled out.

\section{g. Risk and conflict liability}

The results show that concerns were raised by designers, contractors and system providers/manufacturers regarding risk and conflict liability. Grey areas relating to responsibility and liability for structural engineers and specialist engineers lead to conflicts that result in difficulties for contractors regarding working together and coordinating work. Holti et al. (2000) found that, in conventional project delivery, designers typically have the final word in design decisions, whereas in integrated project delivery, design decisions should be made by the team. On the other hand, Hallowell and Toole (2009) pointed out that, in manufacturing construction, the manufactured component must have a proper engineering design because each component has a direct impact on the performance of the final structure. Thus, in the IBS scenario, the acceptance of design decisions is an issue which the challenge relates to risk and conflict liability, especially between structural designers and specialist engineers. System providers/manufacturers experience conflicts with design and supervision issues due to a liability of IBS drawing endorsements and the fees allocated to designers.

\section{h. Contractual and procurement}

The clients, contractors, system providers/manufacturers and installers complained about the client practice of tendering by a project. Clients and designers identified the concept of package tendering as a hindrance to IBS supply chain integration, which affects work performance and quality, especially for contractors and designers. This finding is consistent with information in the literature. Studies have shown that the construction industry and IBS construction experience fragmentation issues related to lowest-price practices. Project tendering has been recognised as a challenge for supply chain integration (Forgues \& Koskela, 2009) and relationship management due to the temporary nature of projects that hinder the continuity of work (Hasnan et al., 2009). Moreover, system providers/manufacturers added the challenge of early involvement at the tendering stage. According to Rashid (2009), the late involvement of system providers following the design stage is a major challenge for integration in IBS project delivery. This lack of early involvement of system providers results in a lack of knowledge transfer from expert sources ( Matipa \& Siamuzwe, 2005).Designers have raised the issue that lack of early proper agreements with system providers/manufacturers results in profit margins that don't match the value of the project because there is no agreement on tender acceptance while the contractors noted difficulties with appointed nominated subcontractor (NSC) by clients and the changes in Design and Build procurement concepts. According to Ward and Holti (2006), pure contractual arrangements and unfair contract conditions present challenges for supply chain integration. Lastly, contractors have raised the issue of clients creating "forced marriages" between designers and contractors, which affects the quality of communication. Lack of cooperation between contractors and consultants and mutual unfamiliarity conflicts with their shared interest in completing the project as one integrated supply chain

\section{Conclusion}

The research findings emerged from the literature and data collected from the research. After data analysis, the findings from the above discussion identified many integration challenges faced by the IBS supply chain. The findings of integration challenges highlighted by the multiple tiers of IBS supply chain revealed the factors that determine the challenges between players to facilitate the integration of supply chain amongst the players. These are grouped into 8 (eight) key categorical themes as (1) lack of sufficient knowledge, understanding and familiarity; (2) attitude and mentality; (3) financial matters; (4) work planning and arrangement; (5) flow and interaction of supply 
chain; (6) guidelines and requirements; (7) risk and conflict liability and (8) contractual and procurement matters. However, various IBS supply chain players ranked the importance of these challenges differently. Challenges, 'lack of skills, knowledge and understanding', the clients, designers, main contractors, and system providers/manufacturers were ranked and prioritised as the major challenge, but the installers ranked the challenges on the behaviour aspect of 'attitude and mentality' as the highest priority. These results suggest that the lowest tiers of the supply chain are more concerned about the attitudes and mentality than the upper tiers. This study has shed clear light of the challenges of improving the integration of supply chains in IBS project procurement in Malaysia. The research findings have expanded the knowledge base of the elements that can encourage the integration of the supply chain and give a new direction to industry professionals (government or private sector) as a benchmark for improving integration supply chain.

\section{Acknowledgements}

The authors would like to thank Universiti Teknologi MARA for providing the opportunity to participate in this conference. Special thanks also go to the reviewers for their invaluable comments on this paper.

\section{References}

Abd Shukor, Ani Saifuza, Mohammad, M. Fadhil, Mahbub, Rohana, \& Halil, F. (2009). Integration of issues and problems of construction supply chain management in industrialised building systems (IBS). Paper presented at the $2^{\text {nd }}$ Construction Industry Research Achievement International Conference (CIRAIC 2009), Kuala Lumpur.

Abd Shukor, Ani Saifuza, Mohammad, M. Fadhil, Mahbub, Rohana, \& Halil, F. (2015). Towards improving integration of supply chain in IBS construction project environment, Procedia Social a $n$ d B e h a v i o r a I S c i e n c e s. 02 (2015) ASEAN-Turkey ASLI conferences on Quality of Life 2015, AcE-BS ver 2; AICQOL 2015, Jakarta

Abdul Rahman, N.A, Zainordin, Z.M, Ahmad, S \& Mahat, S. (2015). Maximization of IBS elements at wet areas in solving leaking problems and promoting better quality control, Procedia Social a n d B e h a v i o r a I S c i e n c e s. 202 ( 2015 ) 424-435 doi: 10.1016/j.sbspro.2015.08.247

Awad, Hussain A. H., \& Nassar, Mohammad Othman. (2010). Supply chain integration: definition and challenges. Paper presented at the Proceedings of the International MultiConference of Engineers and Computer Scientists, Hong Kong.

Baiden, Bernard K. (2006). Framework for the integration of the project delivery team. (Doctor of Philosophy), Loughborough University, Loughborough.

Blismas, Nick, \& Wakefield, Ron. (2008). Offsite manufacture in Australia - barriers and opportunities. Paper presented at the Third International Conference of the Cooperative Research Centre (CRC) for Construction Innovation.

Blismas, Nick, \& Wakefield, Ron. (2009). Drivers, constraints and the future of offsite manufacture in Australia. Construction Innovation, 9(1), 72 83.

Brown, David C. (1999). Working together: tools for an integrated construction supply chain. Southampton, GB, University of Southampton.

CIDB. (2007). Construction industry master plan Malaysia 2006-2015: Construction Industry Development Board (CIDB) Malaysia, Kuala Lumpur. Construction Industry Development Board (CIDB). (2015). Construction Industry Transformation Programme 2016 - 2020. Kuala Lumpur.

Dainty, Andrew R. J., Briscoe, G. H., \& Milllett, Sarah J. (2001). New perspectives on construction supply chain integration. Supply Chain Management: An International Journal, 6(4), 163-173.

Emuze, F., \& Smallwood, J. J. (2011). Conceptual framework for improving the construction supply chain. Paper presented at the 6th Nordic Conference on Construction Economics and Organisation, Danish Society of Engineers Conference Centre, Copenhagen, Denmark.

Forgues, Daniel, \& Koskela, Lauri. (2009). The influence of a collaborative procurement approach using integrated design in construction on project team performance. International Journal of Managing Projects in Business, 2(3), 370-385. doi: 10.1108/175383370910971036

Hallowell, Matthew, \& Toole, T. Michael. (2009). Contemporary design-bid-build model. Journal of Construction Engineering \& Management, 135(6), 540-549. doi: 10.1061/(ASCE)0733-9364 
Haron, Nuzul Azam, Rahman, Hamzah Abdul, \& Hanid, Mahanim. (2009). A literature review of the advantages and barriers to the implementation of industrialised building system (IBS) in construction industry. Malaysian Construction Research Journal, 4(1), 10-14.

Hasnan, Norlena, Ahmad, Hartini, \& Othman, Norhasni. (2009). Construction supply chain integration. Paper presented at the 3rd International Conference on Operations and Supply Chain Management, Malaysia

Holti, Richard, Nicolini, Davide, \& Smalley, Mark. (2000). The handbook of supply chain management: the essentials. London: CIRIA.

Isnin, Z., Ramli, R, Hashim, A.Z, \& Irwan, M. A. (2012). Are House Alterations Sustainable? Journal of Asian Behavioural Studies, 2(5), 13

Jabar, I. Laili, Ismail, Faridah, Aziz, N. Mardhiyah, Janipha ,N.A. Isnaini (2013). Public Participation: Enhancing public perception towards IBS implementation, Procedia Social a n d B e h a v i o r a I S c i e n c e s. 168 ( 2015 ) 61-69 doi: 10.1016/j.sbspro.2014.10.210

Jabar, I. Laili, Ismail, Faridah, Mustafa, A.A. (2013). Issues in manaing construction phase of IBS project, Procedia Social a $\mathrm{n}$ d B e $\mathrm{h}$ a v i o r a I S c i e n c e s. 105 (2013) $81-89$ doi: 10.1016/j.sbspro.2013.07.181

Jitpaiboon, Thawatchai. (2005). The roles of information systems integration in the supply chain integration context - firm perspective. (Doctor of Philosoply Degree in Manufacturing Management), University of Toledo.

Kamar, Kamarul Anuar Mohamad, \& Hamid, Zuhairi Abd. (2011). Supply chain strategy for contractor in adopting industrialised building system (IBS). Australian Journal of Basic and Applied Sciences, 5(12), 2552-2557.

Kennedy, R., \& Sidwell, A. C. (2001). Re-engineering the construction delivery process: The Museum of Tropical Queensland, Townsville - A Case Study. Construction Innovation (Sage Publications, Ltd. ), 1(2), 77-90.

Matipa, Wilfred M, \& Siamuzwe, Valentah M M. (2005). Information and communication technology [ICT] supported supply chain management benefits for construction business in landlocked developing nations. 489-498

Morton, Ralph. (2008). Construction UK: introduction to the industry (2 ed.): Blackwell Publishing.

Nadim, Wafaa, \& Goulding, Jack S. (2010). Offsite production in the UK: the way forward? A UK construction industry perspective. Construction Innovation, 10(2), 181-202.

Pan, Wei, Gibb, A.G. F, \& Dainty, Andrew R. J. (2005). Offsite modern methods of construction in housebuilding : perspectives and practices of Leading UK Housebuilders. Loughborough, Leichester: Loughborough University.

Platten, Andrew, \& Gorse, Christopher. (2010). Supply chain development for major public sector projects. Paper presented at the Procs 26 th Annual ARCOM Conference, Leeds, UK.

Piaw, Chua Yan. (2012). Mastering research methods. Malaysia: McGraw-Hill (Malaysia) Sdn.Bhd. Rashid, Kamaluddin Abdul. (2009). Industrialised building systems: The JKR perspectives. Malaysian Construction Research Journal, 4(1), 1-9.

Rashid, Kamaluddin Abdul. (2009). Industrialised building systems: The JKR perspectives. Malaysian Construction Research Journal, 4(1), 1-9. Vrijhoef, Ruben, \& Koskela, Lauri. (1999). Roles of supply chain management in construction. Paper presented at the Proceedings IGLC-7, University of California, USA

Ward, Don, \& Holti, Richard. (2006). Towards more effective integration in UK construction Construction Excellence in the built environment (pp. $1-60)$.

Warszawski, Abraham. (1999). Industrialized and automated building systems - a managerial approach. London: E \& FN Spoon.

Xue, Xiaolong, Li, Xiaodong, Shen, Qiping, \& Wang, Yaowu. (2005). An agent-based framework for supply chain coordination in construction. Automation in Construction, 14, 413-430. doi: 10.1016/j.autcon.2004.08.010 